\title{
A SOUTH SULAWESI HERO AND VILLAIN: QAHHAR MUDZAKKAR (KAHAR MUZAKKAR) AND HIS LEGACY
}

\author{
Stephen Charles Druce \\ Academy of Brunei Studies, Universiti Brunei Darussalam, \\ Tungku Link, Gadong BE 1410, Brunei \\ E-mail: stephen.druce@ubd.edu.bn
}

Published online: 15 July 2020

To cite this article: Druce, S. C. 2020. A South Sulawesi hero and villain: Qahhar Mudzakkar (Kahar Muzakkar) and his legacy. International Journal of Asia Pacific Studies 16 (2): 151-179. https://doi.org/10.21315/ijaps2020.16.2.8

To link to this article: https://doi.org/10.21315/ijaps2020.16.2.8

\begin{abstract}
The Darul Islam rebellion against the central Indonesian government in the immediate post-independence period was largely dependent on charismatic leaders who came to prominence during the struggle against the Dutch. The charismatic leader of this rebellion in South Sulawesi was Qahhar Mudzakkar (also spelt "Kahar Muzakkar"), whose conflict with the central government and army began in 1950 when he was overlooked as commander of a special Sulawesi brigade and many of the Sulawesi guerrillas who had fought against the Dutch were discarded as the Indonesian Army restructured. Qahhar led the men into the jungle and began a rebellion that would last for 15 years. In 1953, he proclaimed an Islamic state, thus joining the Darul Islam movement. Important factors in the rebellion's genesis and momentum were bitterness at the perceived injustice and rejection of Qahhar and the Sulawesi guerrillas by the central government and army and increasing Javanese hegemony in the region. Other causal factors debated include Islam, various political ideas, and several South Sulawesi cultural concepts. What seems clear is that Qahhar had developed ideas that were seemingly incompatible with "traditional" notions of South Sulawesi culture. He preached a form of "Islamic socialism," aimed to implement strict shari'ah law, eradicate aristocratic titles, pre-Islamic rituals, and Sufi orders. Forty-eight years after his death, Qahhar Mudzakkar continues to divide opinion and inspire new generations. The paper focuses on three main aspects of Qahhar Mudzakkar and his legacy. The first examines traditional leadership in South Sulawesi, including the cultural characteristics expected of leaders and draws comparisons
\end{abstract}


with the 17th century. The second examines memories and perceptions of Qahhar and the rebellion related to me by people who lived through the period. The third looks at how Qahhar is perceived and the role he plays in modern day South Sulawesi, particularly in local politics as many see Preparatory Committee for the Application of Islamic Laws (KPPSI) as a continuation of Qahhar's struggle. The head of KPPSI is Abdul Aziz Qahhar Mudzakkar, a son of Qahhar Mudzakkar.

Keywords: Qahhar Mudzakkar, Kahar Muzakkar, South Sulawesi, Indonesia, Sulawesi guerrillas

\section{INTRODUCTION ${ }^{1}$}

The Darul Islam rebellion against the central Indonesian government in the immediate post-independence period was largely dependent on charismatic leaders who came to prominence during the nationalist struggle against the Dutch. In South Sulawesi the charismatic leader was Qahhar Mudzakkar (also spelt Kahar Muzakkar), a leading Republican commander who had organised a force of South Sulawesi fighters in the struggle against the Dutch in Java. ${ }^{2}$ After Sulawesi officially joined the Republic of Indonesia in 1950, Qahhar appears to have believed he would be made commander in South Sulawesi and that the guerrilla fighters in the region who had fought for an independent Indonesia would be given official status in the Indonesian Army. Qahhar's conflict with the central Indonesian government began when neither expectation materialised: he was overlooked for the command and most of the South Sulawesi guerrilla fighters were discarded in the Indonesian Army's restructuring. Qahhar returned to Sulawesi from Java in 1950, initially called there to negotiate with the guerrillas regarding their continuing demands to be incorporated into the Indonesian Army as a special Hasanuddin Division with Qahhar as commander. However, Qahhar sided with the guerrillas and pressed their demands, which were rejected. He then led the men into the jungle, beginning a rebellion against the Indonesian central government that would last 15 years. $^{3}$ In 1953, several years into the rebellion, Qahhar responded to Kartosowiro's offer for South Sulawesi to join West Java as part of the Darul Islam and he thus proclaimed South Sulawesi an Islamic state. The rebellion ended in 1965, when the Indonesian Army finally killed Qahhar.

The rejection of Qahhar and the South Sulawesi guerrillas by the Indonesian Army was clearly an important factor in the origins of the rebellion against the central Indonesian government. Equally important was Qahhar's antipathy towards an increasingly centralised government in Java 
and Javanese political and cultural hegemony in Sulawesi, which was shared by many people in South Sulawesi at the time (Harvey 1974; Lineton 1975: 23; van Dijk 1981). Javanese dominance of the new republic included not only an increasing number of Javanese troops in Sulawesi, but also government leaders and Javanese culture. The question of whether Qahhar's fifteen year rebellion was predominantly driven by these or other factors, such as Islam, political ideals, bitterness or various combinations of the aforementioned, perhaps inflamed by the South Sulawesi concepts of siriq and pessé, is, however, subject to debate. ${ }^{4}$

In modern South Sulawesi politics, Qahhar's Islamic credentials are of the upmost importance, particularly to those who continue the Darul Islam struggle through constitutional means and portray Qahhar as an Islamic hero who fought for Islamic ideals but was betrayed by the central government. Others see Qahhar simply as a rebel whose actions caused destruction and suffering. What is clear is that long before Qahhar began his rebellion he had developed radical ideas that were seemingly incompatible with "traditional" notions of South Sulawesi culture. This was most evident during the Japanese occupation when he openly opposed the position and role of the Luwu aristocracy, who subsequently banished him. From 1953, Qahhar preached a form of "Islamic socialism" and aimed to implement strict shari'ah law and eradicate aristocratic titles, the feudal system, pre-Islamic rituals, and Sufi orders. Fifty years after his death, Qahhar Mudzakkar continues to divide opinion and inspire new generations.

The Darul Islam rebellion permeated South Sulawesi society and continues to permeate memories in the 21 st century. This article adds a culturally informed, up-to-date examination of local perceptions of Qahhar Mudzakkar to an already extensive literature. I focus on three main aspects of Qahhar Mudzakkar and his legacy. The first is traditional leadership in South Sulawesi and the relevant cultural characteristics leaders are expected to possess. Here, comparisons are made between Qahhar and the 17thcentury Bugis leader, Arung Palakka. The second focus examines memories and perceptions of Qahhar and the rebellion related to me by people who lived through or took part in the rebellion. From this information, an attempt is made to understand the underlying reasons for the support Qahhar and the rebellion received among rural populations. The third is how Qahhar is perceived and portrayed in modern day South Sulawesi, in particular, his renewed importance in local politics where his rebellion is continued by political movements inspired by him that use constitutional means. The most important of these is the Komite Persiapan Pelaksanaan Syariat Islam (KPPSI, 
Preparatory Committee for the Application of Islamic Laws), which is led by Abdul Aziz Kahar Muzakkar, Qahhar Mudzakkar's son, who has stood as a candidate in the South Sulawesi Governorship election in 2007 and a vice candidate in 2012 and 2018.

\section{BACKGROUND TO QAHHAR MUDZAKKAR AND THE REBELLION ${ }^{5}$}

The second of 13 children, Qahhar Mudzakkar was born in Lanipa in Luwu in March 1921. ${ }^{6}$ His father was a successful businessman, which allowed the family to give Qahhar a formal education, a luxury few children in South Sulawesi enjoyed at that time, especially outside Makassar city. ${ }^{7}$ After completing elementary school in 1934, Qahhar went to the Muhammadiyah Standard School in Palopo (capital of Luwu). Then in 1938, his parents sent him to Solo in Central Java to attend the Muallimin Muhammadiyah School, an Islamic teacher's school, where he studied for the next three years. It is possible that Qahhar began to develop more radical political and religious ideas while studying at Muallimin, as he came into contact with several well-known ulama, Muslim reformists and nationalists. It also appears that it was at this time that Qahhar changed his name from La Domeng to Qahhar Mudzakkar, which was perhaps inspired by his admiration for Abdul Kahar Muzakkir, a prominent modernist Muslim who was also a Muhammadiyah youth leader and teacher at the school (Harvey 1974: 181; Hamdan Juhannis 2006: 32). ${ }^{8}$ Given his education and the opportunities this presented to meet prominent ulama, Qahhar was to some extent a product of early 20th century modernist Muslim movements and modern Islamic education.

Qahhar, however, did not complete his full schooling at Muallimin and returned to Palopo in 1941, where he became a teacher in a Muhammadiyah school and a member of Hisbul Wathan, a Muhammadiyah youth organisation. According to Mattulada (1983: 176), the reason Qahhar did not finish his studies was because at 18 he married Siti Walinah from Solo. Hamdan Juhannis (2006: 33-34) suggests other reasons, namely Qahhar lacked interest in formal education and appears to have been of average academic ability. Hamdan Juhannis goes on to say that Qahhar's talents were creativity and problem solving, and that he was an unconventional thinker who took a strong stance on principles. ${ }^{9}$ In relation to Qahhar's personality when he was in the Indonesian Army, Harvey (1974: 181) reports that Qahhar was considered a good fighter but not a good soldier, as he did not like taking orders and "was proud, strong-willed, opinionated" and "stubborn." 
Qahhar's unconventional, principled and opinionated approach to life appears to have been applied to his activities with Hisbul Wathan, which soon brought him into conflict with traditional authority in Luwu. He openly preached against the traditional feudal system and opposed aristocratic titles and social stratification in society, even openly advocating the abolishment of the aristocracy (Harvey 1974: 182). Qahhar's views enraged the local aristocracy who eventually took action against him. In 1943, the Luwu adat council decided his punishment would be ripaoppangi-tana (to place something face down and cover it with earth as if it no longer existed [Matthes 1874: 789-790]), which effectively meant Qahhar was ostracised and banished from the kingdom.

Qahhar then returned to Solo and became involved in business, running a small trading company for the duration of the Japanese occupation. When the Dutch returned to Indonesia, he joined the struggle against them and became a prominent nationalist fighter, eventually rising to the position of lieutenant colonel. In 1945, he was involved in the formation of Kebaktian Rakjat Indonesia Sulawesi (KRIS, Loyalty of the Indonesian People from Sulawesi), composed mainly of Christian Minahasa people from North Sulawesi, and became its first secretary. After leaving KRIS because of internal divisions, Qahhar founded the Batalion Kesatuan Indonesia (BKI, The United Indonesian Battalion) that was made up men from the Outer Islands, many of whom were of South Sulawesi origin and had been released from Nusakembangan and Cilacap Prisons. According to Hamdan Juhannis (2006: 39), it was Qahhar who negotiated the release of these prisoners. After receiving basic military training, they became Qahhar's men. In 1946, Qahhar was given the task of forming the Tentara Republik Indonesia Persiapan Sulawesi (TRI-PS, Sulawesi Preparatory Unit of the Army of the Republic of Indonesia), which involved organising men to send to Sulawesi to fight against the Dutch. While Qahhar was commander of this unit and controlled the men (Harvey 1974: 183), he remained in Java himself and from his remaining men in 1947 formed a battalion called Barisan Berani Mati (BBM, Daredevil Unit) that acted as a front-line commando unit in East Java (van Dijk 1981: 160).

Qahhar was later made commander of the Komando Grup Seberang (KGS, Commando Group for the Outer Islands), which coordinated various guerrilla units in Kalimantan, Sulawesi, the Moluccas and Nusa Tenggara. After South Sulawesi's official incorporation into the Republic of Indonesia, the KGS was disbanded and Qahhar harboured strong hopes of being made Commander of Sulawesi, which he believed to be his "historical right" (Harvey 1974: 188). According to Harvey $(1974: 188,198)$, however, the 
professionals who controlled the army at this time never considered Qahhar for such a position of responsibility as they did not believe he could be fully trusted. ${ }^{10}$ In 1949, as head of KGS, Qahhar had sent some of his men to South Sulawesi in order to organise existing guerrilla units into unified battalions as the Kesatuan Gerilja Sulawesi Selatan (KGSS, United South Sulawesi Guerrillas). Following Dutch recognition of Indonesian independence, the KGSS formally requested incorporation into the Tentara Nasional Indonesia (TNI, National Indonesian Army) as a Hasanuddin Division under Qahhar's command. This request was rejected and tensions escalated when only about one third of the men would be incorporated into the TNI and the remainder disbanded (van Dijk 1981: 181). This led to increased tensions and eventually fighting broke out between the KGSS and some of the TNI troops stationed in South Sulawesi. Qahhar was called to South Sulawesi in order to negotiate with the guerrillas. However, he took their side and led them into the jungle to begin rebellion, effectively fulfilling his "historical right" by becoming their leader. By the early 1960s, the rebellion began to falter and in 1965, the TNI finally shot and killed Qahhar in Southeast Sulawesi. Apparently, his body was flown to Makassar to be identified and later buried in an unknown and unmarked grave. Qahhar's death, however, remains hotly disputed in South Sulawesi with many believing he simply went away but would return one day.

\section{LEADERS, LEADERSHIP AND STATUS IN "TRADITIONAL" SOUTH SULAWESI}

In "traditional" South Sulawesi society, status was ascribed and this largely determined a person's opportunities to become a ruler or hold political office. Justification for this social differentiation between nobles on the one hand and commoners and slaves on the other, is set out in numerous oral and written genealogies that trace the origins of the various kingdoms ruling elite a class of white-blooded founders, mainly tomanurung (generally male) who descended from the Upperworld, or totompoq (generally female) who arose from the Underworld. White-blood is an important concept as in theory the elite were ranked according to their level of this blood, which diluted when high-ranking males took wives from commoner or slave classes. This resulted in a complex system of ranks where a person's level of white blood determined their status. As status markers for kin groups, women were forbidden to marry below their rank (Pelras 1996: 169-170; Druce 2009: 161-163). In reality, there was a degree of fluidity in the system as lower ranking members from the ruling 
elite could rise in the system through achievement and personal qualities. As Susan Millar (1989: 29) points out, this would not be seen as acquisition of status but rather a recognition or re-evaluation of status. ${ }^{11}$ Political office was thus not necessarily hereditary and personal qualities played an important role in attaining positions, or becoming ruler, as long as the candidate was from the higher reaches of the group. ${ }^{12}$

According to the Bugis latoa traditions, appropriate descent is a quality needed to become a good leader, together with four other characteristics I outline below. ${ }^{13}$ Qahhar's parents appear to have been from the very lowest echelon of the Luwu nobility, and his wider family appear to have been mainly commoners. ${ }^{14}$ In the traditional system briefly described above, Qahhar's background and comparatively low-level of descent meant that he would not have had the opportunity to rise to any significant or influential level in society, certainly not to the level of an influential leader. Qahhar, however, lived in a time of great change that saw the development of modern schooling, newspapers and books in South Sulawesi, the rise of reformist and modernist Islamic movements in Indonesia that challenged the hereditary elite, the Japanese occupation, and the struggle against the Dutch to create an independent Indonesia. All of these are factors that threatened the traditional social order and provided people like Qahhar with opportunities to come to prominence and question traditional society.

\section{QAHHAR, ARUNG PALAKKA AND SOUTH SULAWESI CULTURAL CONCEPTS}

In comparing Qahhar to pre-colonial leaders, the most obvious figure is Arung Palakka, who like Qahhar rose to a position of power, as ruler of the Bugis kingdom of Boné, in the turbulent 17th century when the Bugis were dominated by the Makasar kingdoms of Gowa and Talloq. Like Qahhar, Arung Palakka is labelled a villain by official Indonesian histories as he allied himself with the Dutch in order to free the Bugis from Makasar domination, an alliance that successfully led to the fall of the Gowa-Talloq Empire. ${ }^{15}$ Both men were also charismatic. The Dutch became well aware of Arung Palakka's attraction and pull he had on the Bugis and his great "esteem" and "power" over the people as they plotted to bring down Gowa and Talloq (Andaya 1981: 83). Similarly to Arung Palakka, Qahhar could move people to action with his speeches and, as Harvey (1974: 183) notes, he possessed those leadership qualities that cannot be taught. Unlike Qahhar, however, Arung Palakka was from the 
higher, but not the highest, echelons of the ruling elite; his grandfather was ruler of Boné and his mother the datu (ruler) of Marioriwawo, an important tributary of the kingdom of Soppeng.

\section{Qahhar and Arung Palakka as to warani}

Despite the widely differing backgrounds, there are certain cultural concepts that link Arung Palakka and Qahhar. In addition to appropriate descent, the latoa sets out four essential characteristics that are required to become a good leader: to be brave (warani), clever (macca), religious (panrita) and wealthy (sugiq). While the latoa essentially sets out ideals, these characteristics are highly valued in Bugis society and would be expected of a leader (Pelras 1996: 209-215). Qahhar may not have been rich but appears to have been affluent, and perhaps seen by his followers as having these four traditional leadership characteristics. In relation to perceptions of Qahhar and Arung Palakka, the characteristics that stand out in stories told about them are warani and macca. Both men are acclaimed for their intelligence and, in particular, for being to warani (brave people), with many of the stories told about them sharing similar features to typical South Sulawesi to warani stories.

All to warani stories relating to Qahhar and Arung Palakka emphasise three qualities. The first of these is physical prowess, often exaggerated, and includes sexual virility. In South Sulawesi stories, Arung Palakka is described as a huge man of enormous strength who was so well endowed that it was impossible for a woman to lie with him long enough to conceive. ${ }^{16}$ Qahhar's physical strength is also exaggerated by some claiming that he could carry a buffalo and lift heavy inanimate objects no other man could. Some informants in Luwu also claim that even when still a child in his early teens Qahhar had fought with and beaten much older men. ${ }^{17}$ His sexual virility is derived from the large number of wives he is said to have had, which according to Bahar Mattalioe (1965) was nine. Stories told about Qahhar often claim he had more than nine wives but a specific number is never given, just estimates of between seven and 15. Pelras (2000:30) reports that a fatwah pronounced by an ulama who followed Qahhar decreed that as a "warrior of the faith" Qahhar was permitted to take more wives than is usually acceptable in Islam. Qahhar's large number of wives, exaggerated or not, rarely brings condemnation but rather serves to enhance his reputation and standing in South Sulawesi society. ${ }^{18}$ The second quality emphasised is incredible bravery, for which Arung Palakka and Qahhar there is contemporary documentation from their respective times. The bravery and recklessness of Arung Palakka in battle 
became an important concern for the Dutch, as he was vital to the DutchBugis alliance against the Gowa-Talloq Empire. Eventually, the Dutch even assigned one of their own men as a bodyguard to ensure no harm came to him (Andaya 1981: 83). In 1945, Qahhar was a member of Sukarno and Hatta's bodyguard and according to many accounts, armed with just a machete he was the person prepared to protect the two leaders from the Japanese as they attempted to break-up a meeting where Sukarno was going to give a speech, an incident for which there is photographic evidence (Hamdan Juhannis 2006: 38). In South Sulawesi this story is often exaggerated with Qahhar standing alone with his machete facing the Japanese, who eventually back away from Qahhar out of fear or respect for bravery.

The third quality common in the stories is supernatural power, which both men are believed to have possessed and which is said to come from a magical science known in Bugis as paddissengeng. According to these stories, Qahhar and Arung Palakka are said to have been invulnerable to knives, swords and bullets, and whenever the need arose could simply vanish. There are stories that tell of how both Dutch and Indonesian soldiers shot at Qahhar at close range but none of the bullets could penetrate his body. For those people who dispute Qahhar was killed in 1965, the belief that he had supernatural powers is sufficient proof that the Indonesian Army could not have shot him as he was invulnerable to their bullets. Some informants who accept that Qahhar was shot and killed in 1965, claim that it was only possible because he was about to take a shower and had removed the amulet that protected him.

\section{Siriq and Pessé}

Another cultural concept often mentioned in South Sulawesi as justification and stimulus for both Qahhar's and Arung Palakka's actions is siriq (selfworth, shame), which is found among all ethnic groups of South Sulawesi. If a person, or a member of their family or wider community is shamed, insulted or offended they are expected to take action in order to redress the situation and regain their self-respect and honour, which can include violence. A person who does not react when their siriq is challenged would be regarded with contempt. As Hamid Abdullah (1985: 37) states, siriq is closely associated with life itself and all can be sacrificed for its sake. A further related concept is pessé, which literally means "pain" or "to feel pain," but is used in a wider cultural sense to mean solidarity, empathy and commiseration with one's community or patriots, so as to feel their pain. 
Andaya $(1981: 15-17,70)$ has examined siriq and pessé in relation to Arung Palakka in his determination to free the Bugis from Gowa-Talloq domination. He considers these concepts "essential" to understanding events and their background as only by defeating Gowa-Talloq could Arung Palakka restore "his and his people's siri" so that they could "once again be able to hold their heads high in South Sulawesi."

Anhar Gonggong (1992) has argued that siriq and pessé played major roles in pushing Qahhar towards rebellion and the main reason why a former "patriot became a rebel." He also argues that Islam sustained these concepts. According to Anhar Gonggong, Qahhar was attempting to restore his siriq, which had been affronted on various occasions, such as when he was sentenced to ripaoppangi-tana by the Luwu adat council. The struggle against the Dutch, Anhar Gonggong argues, presented Qahhar with the opportunity to fight and regain his siriq. After the formation of the Republic of Indonesia, his siriq was again invoked when rejected as Commander of South Sulawesi, which he felt was his right. Anhar Gonggong believes this could have been rectified had the army acceded to calls for a Hasanuddin Division to be formed for the men with Qahhar as commander. As a leader, he felt morally bound to defend the men and felt pessé for their plight, as they did for his. As no solution could be found through peaceful means, Anhar Gonggong argues that Qahhar and his followers had no alternative but to rebel against the government. In relation to the rebellion's origin, my informants in South Sulawesi often mentioned siriq as a reason and tended to agree that it acted as a major inspiration in Qahhar's actions, as we shall see below, and justification to start a rebellion.

\section{ISLAM OR REGIONALISM?}

Qahhar's rebellion received considerable support from local populations in rural areas. Most scholarly studies on the rebellion argue that the underlying reason for this support was not so much inspired by Islam or the Darul Islam idea, which Qahhar only espoused almost three years into the rebellion, but derived from two main factors. One was the anti-Javanese and anti-centralist sentiments that had developed in the region. The other was empathy with the plight and perceived ill treatment of Qahhar and the Sulawesi guerrillas, with whom the people shared ethnic, cultural, linguistic and, in some cases, family ties (Harvey 1974; Lineton 1975; van Dijk 1981; Ichlasul Amal 1992). Barbra Harvey's work, which deals extensively with Qahhar, is perhaps the most important of these studies. Before carrying out fieldwork 
in 1971-1972, Harvey had gained first-hand experience of this tumultuous period in Indonesian history when working for the United States Information Service in Surabaya from 1961-1964. Concerned with national cohesion and the relationship between the centre and regions from the perspective of the latter, she focused on the South Sulawesi rebellion and its socio-economic and political bases, which included an understanding of local societies and their modern history. Lineton (1975: 23), like Harvey, carried out intensive fieldwork in South Sulawesi in the early 1970s when the memories and reasons for the rebellion were fresher in people's minds than today. She writes that wide spread support for Qahhar was because there was a general desire "to attain independence from foreign domination" that was "threatened once more with the creation of the Java-centred Republic of Indonesia" and had less to do with "sectarian motives."19

After beginning the rebellion, Qahhar produced a number of writings but there is little reference to Islam or an Islamic state in these writings before he joined Darul Islam, and it is only after 1953 that a clear Islamic orientation is evident (Hamdan Juhannis 2006: 61). Harvey (1974: 250-253) suggests that during the early years of the 1950s, Qahhar may have been torn between Islam and communism as an ideological basis for the rebellion. During the struggle against the Dutch, Qahhar had worked in the Biro Perdjuangan that was under the influence of Amir Sjarifuddin and Djokosujono and others from the Indonesian left (Harvey 1974: 249), although the extent of their impact on Qahhar's thinking is not altogether clear. Both Darul Islam and Partai Komunis Indonesia (PKI, Indonesian Communist Party) members certainly petitioned Qahhar to join them and, according to Harvey's sources, Qahhar sought the opinion of his commanders as to which they should choose. The former was chosen and Harvey argues that the main reason for this choice was that a rebellion based on Islam stood a greater chance of attracting progressive members of the still influential nobility, who would never accept communism. Furthermore, it also stood a greater chance of gaining support from the mainly Muslim population of South Sulawesi and the Muhammadiyah networks. Only after Darul Islam was chosen did Qahhar then order the execution of the two PKI members who had been sent to negotiate with him (Harvey 1974: 255). Harvey essentially argues the main reason Qahhar joined Darul Islam was because he saw it as a way to justify the continuation of the rebellion and garner support, especially as the rebellion's initial ideological basis shared too many similarities with ideas expressed by Sukarno at the time and would ultimately be ineffectual. Qahhar had in fact continued to refer to the Pancasila philosophy until in 1952 when he put forward his own but similar 
version called the Trisila (Three Pillars): belief in one God, social justice and humanitarianism (van Dijk 1981: 188). It is tempting to conclude that in this move Qahhar was attempting to shift the ideological basis of the rebellion in order to make it appear different to that constantly expressed by Sukarno. If Harvey is correct, this shift to Trisila was not sufficient to sustain the rebellion and thus led Qahhar to choose a more radical basis.

Many of the publications that claim Islam was the inspiration and core driving force of Qahhar and the rebellion are academically weak, vague and subjective. Some were written by Qahhar's former followers, such as his former guard Tommy Thompson (2002). Others, such as Wanua Tangke's (2002) book are little more than collections of rumours and tales, which while portraying Qahhar as a powerful Islamic figure essentially capitalises on the popular perception that he is still alive. An important exception to these works is Hamdan Juhannis' $2006 \mathrm{PhD}$ thesis. Written at a time of growing Islamic conservatism in Indonesia, he specifically sets out to present an "Islamiccentric" perspective on the South Sulawesi rebellion and to link the rebellion to post-New Order Islamic groups calling for shari'ah law in order to argue that they collectively represent locally rooted movements for "formalist Islam. ${ }^{20} \mathrm{He}$ places considerable emphasis on Qahhar's Islamic education and Islamic orientation before joining Darul Islam, and the importance and depth of commitment to Islam by some of his core followers in South Sulawesi, partly derived from the Muhammadiyah networks that developed from the 1920s. He rejects Harvey's argument, summarised above, that Darul Islam was simply an "ideologised tool" - a "political device." He does not reject the importance of the demobilisation and regionalist issues in the rebellion's origin but does argue that the emergence of Darul Islam as the rebellion's basis was a natural process and progression given the Islamic orientation of Qahhar and some core members. He also argues that the lack of evident Islamic input and seemingly left-wing terminology in Qahhar's writings before joining Darul Islam does not necessarily mean that his struggle had no Islamic sentiment or was influenced by communism. ${ }^{21}$ Hamdan Juhannis further notes that Qahhar continued to use similar left-wing terminology after joining Darul Islam and purging of any communist influences among his followers (Hamdan Juhannis 2006: 63). This terminology included terms such as "common people," "real struggle," "real freedom" and "labourers," 
as well as talking about establishing true democracy among the lower classes that would spread upwards and eliminate feudalism. ${ }^{22}$

Hamdan Juhannis is correct that Qahhar did continue to use left-wing terminology after joining Darul Islam and while his ideas on Islam are set out in these later writings, what comes across most forcefully in his writings are strong anti-centralist and anti-Javanese sentiment. He refers to Sukarno as a nihilist whose aim is to realise the imperial ambitions of the Javanese Majapahit kingdom and impose this imperialism on all non-Javanese people of Indonesia. He also states that the struggle for independence was not simply against Dutch and Japanese domination but also a struggle by all Indonesian ethnic groups to be free of Indonesian feudalism. Qahhar further argues for a federal system of government free of Javanese domination that would reflect the social and cultural realities of Indonesia. ${ }^{23}$ Qahhar's continual emphasis on the eradication of feudalism appears deep-rooted and perhaps derived from his experiences growing up in Luwu and his conflict with the kingdom's aristocracy leading to his banishment.

From existing publications, it is not easy to gauge the level of support Qahhar had for his more radical ideas, particularly relating to Islam, among rural communities of the time. This is also true in relation to some of the rebels who joined Qahhar, a number of whom belonged to Sufi orders outlawed by Qahhar after joining the Darul Islam but members continued to practise in secret (Bruinessen 1991: 265). Furthermore, some of Qahhar's commanders rejected membership of Darul Islam and consequently split from Qahhar. For example, Usman Balo, who had led a group of fighters in Sulawesi against the Dutch and later joined Qahhar's rebellion, refused to follow him into Darul Islam. Usman Balo and his men continued the rebellion for a time based on regionalist secular issues before going over to the Republican side. ${ }^{24}$ Following this split, the troops of Usman Balo and Qahhar clashed on several occasions. Other former nationalist fighters and commanders who split from Qahhar at this time because they rejected Darul Islam were Andi Sose and Aziz Taba, who joined the Republicans (Harvey 1974; Hamdan Juhannis 2006: $56-57){ }^{25}$

In modern day South Sulawesi politics, Qahhar's Islamic credentials are important as organisations such as KPPSI portray Qahhar as a national hero of Indonesian independence and more importantly, an Islamic leader who fought for Islamic ideas and shari'ah law. I examine Qahhar's role in modern politics below, after an analysis of memories and perceptions of Qahhar and the rebellion, which attempts to examine the reasons for the support given to Qahhar and his struggle in rural South Sulawesi. 


\section{MEMORIES AND PERCEPTIONS OF QAHHAR AND THE REBELLION}

My interest in Qahhar Mudzakkar and the Darul Islam rebellion in South Sulawesi came about indirectly while carrying out research on early South Sulawesi history, roughly the period from 1200 to $1600 \mathrm{CE} .{ }^{26}$ Although the period I was researching came to an end over 400 years before Qahhar was born, his actions and those of his men were linked to my research. Locating historical villages was sometimes difficult as during the rebellion many were abandoned, forcibly cleared, or burnt down. After the rebellion, residents returned to some of these villages or re-established them several kilometres away from their former location, while others were never resettled. Qahhar and the rebels also destroyed or defaced keramat sites (sacred places where offerings and requests are made to ancestors or spirits) as they considered them unIslamic, burned Bugis and Makasar manuscripts, old style houses and houses that displayed symbols of the nobility. They also attacked the bissu (pre-Islamic transvestite ritual specialists) or forced them to wear male clothing and carry out hard manual labour, and destroyed the regalia of numerous polities that connected the ruling elite to the founding ancestors. When collecting traditions about the distant past, I met many informants who knew less about the oral traditions I was interested to hear but did want to speak about Qahhar and the rebellion.

Two people I spoke with at length about the rebellion were palontaraq, who in traditional society are people skilled in reading, writing and understanding Bugis and Makasar manuscripts. Such people would have been a target for the rebels, especially as they keep knowledge of the pre-Islamic past, including the genealogies of the ruling elite. One of these palontaraq was particularly well known and regarded as a leading authority, the other lived in the Soppeng region and was known locally. Both collected Bugis manuscripts, copying them either by hand or via a photocopy machine. The former had amassed a large collection related to all South Sulawesi, the latter a much smaller collection concerned mainly with Soppeng but included royal genealogies of all kingdoms.

To my surprise, both men had supported the Darul Islam movement and, during the rebellion, had even burned manuscripts; they were not recognised palontaraq at the time. The Soppeng palontaraq had been an active rebel involved in fighting. When he first informed me of his past I was surprised as earlier that day he had introduced me to a leading noble lady in Marioriwawo in Soppeng and entreated me to act with the upmost respect in her presence, likening her to Queen Elizabeth. 
Thirty-five years or so on from the Darul Islam rebellion, it was clear that the views of these two men regarding the rebellion, traditional society in general and their interpretation of Islam had changed significantly and both had become more interested in their culture and its past. Both were pious Muslims and while the idea of a more Islamic society remained appealing to them, although not necessarily the one proposed by Qahhar, they also saw a continuing important role for more traditional culture and society. Both men acknowledged the importance of the regionalist factor in the rebellion but stated that what had inspired them to join the rebellion was both Islam and Qahhar himself. Reflecting on the rebellion, both men believed it had been a mistake and looked upon the time as one of instability and uncertainty for Indonesia, when many mistakes were made. They appreciated the stability of the post-rebellion period but remained great admirers of Qahhar.

Similar to the two palontaraq, many older people I spoke to about Qahhar and the rebellion in general look back at the time as a period of instability. The oldest members of this group had lived through the Japanese occupation, the return of the Dutch and Westerling's atrocities, the Darul Islam rebellion and finally, the upheavals and killings of the mid-1960s when the New Order rose to power. ${ }^{27}$ Perhaps two thirds of these older people had participated in the rebellion, or at least given it their support (not always voluntarily), but the vast majority were thankful for the stability and safety that the region experienced during the New Order period. ${ }^{28}$

The manner in which people simultaneously admire Qahhar and appreciate the end of the rebellion raises questions about those who had joined or supported the rebellion. What was their motivation, Qahhar, Islam or regionalism, or perhaps even siriq? And what did they think had motivated Qahhar?

To many, siriq appeared to be one readily understandable reason for the rebellion and the actions of Qahhar and his fighters, who they believed were mistreated by the central government. They understood how shamed Qahhar and his men would have felt and that rebelling against those responsible would help them to regain their honour. Some said they felt pessé for Qahhar and the fighters and this had led them to join, especially those whose wider family had been members. I personally doubt that siriq could have sustained the rebellion for fifteen 15 years but local perceptions clearly consider it to have been an important factor. In relation to this, as the rebels were all local people and the Indonesia Army they fought against were mainly Javanese, commonly referred to as "Tentara Jawa" (Javanese Army) or "Tentara Kota" (City Army), one can readily understand that there was a strong sense of empathy. 
Anti-Javanese sentiment too was important. In these rural areas, the impression they had was that after Indonesian independence was won South Sulawesi become dominated by outsiders, mainly Javanese and some Minahasa, who were simply replacing the Dutch. Many thought that these imported "foreigners" and the central government looked down on local people and regarded them as backward, while they believed it should have been themselves who determined their own future. Some anti-centralist/antiJavanese feeling persists and the recent regional autonomy laws were widely supported as a means of promoting their own culture and allowing the people of the region to play an important role in directing its future. At the same time, over the New Order period an Indonesian identity, or at least as sense of belonging to the nation, had developed, something that was absent in the 1950s.

Islam was also given as a reason for supporting the rebellion but the extent of its stimulus varied. For some, Islam had clearly been the main inspiration, a number of whom still harboured ambitions for the creation of an Islamic state for South Sulawesi. They saw the rebellion in mainly Islamic terms and believed that Sukarno and the founders of the republic had betrayed Islam. ${ }^{29}$ While many did mention Islam as a reason, most could not elaborate on the ideals and aims of Darul Islam apart from that the idea was to make South Sulawesi an Islamic state that would be governed by shari'ah law. Many also admitted that their knowledge of Islam had been limited before the rebellion and the Darul Islam period was one when their knowledge of the religion deepened as the rebels gave them religious instruction. For these people, Islam was therefore not a main reason for their initial support or involvement in the rebellion but in many cases, it did become important after they had received religious instruction. A much deeper understanding of Islam was evident among those people for whom Islam had clearly been the main inspiration in joining the rebellion.

A major factor for many in their support for the rebellion was Qahhar himself. Even those who had never met or seen Qahhar had heard stories about him that inspired them and made them feel proud that he was from South Sulawesi. Those who had met Qahhar or heard him give talks remained in awe of him, emphasising his incredible charisma and the inspiration he gave. It was often said that anyone who heard Qahhar give a speech would follow him. While most people were also adamant that Qahhar was a devout Muslim and Muslim leader, it was not so much this quality that people emphasised when talking about him. Rather, it was Qahhar's charisma, bravery, prowess, siriq and supernatural powers. For many people who followed or supported 
Qahhar, these qualities appear to have been at least as important, and perhaps more so, than Qahhar's Islamic credentials in their devotion to him. This is not to say that Islam was not an important factor, but it was just one of many qualities that people in South Sulawesi expect of a leader. Those who believed Qahhar still to be alive were in no doubt that upon his return people would follow him again. Many other people simply wanted to look to the future. ${ }^{30}$

On a final note of memories, it should not be forgotten that it was a period where huge numbers of people suffered, something that many informants emphasised. For much of the 1950s, the rebels controlled most rural areas and the people living there had little choice but to join or cooperate with them. Many people were caught between the rebels and the Indonesian Army, who often burned their rice-fields and other crops to cut off food supplies and income to the rebels. Such actions caused immense suffering in rural areas and drove some to join the rebellion or simply flee their homes to escape both sides.

As Lineton (1975: 24) was informed in the early 1970s by an official in Wajo:

During the rebellion, three-quarters of Wajo' was in the hands of the rebels... If people did not want to join them, they had to move to Sengkang or Makassar or merantau [to emigrate in search of a livelihood]. In Peneki (on the coast), practically all the houses were destroyed - the rebels burnt the houses of those who did not join them, then the army burnt the houses of those who did.

Options open to those who did flee were limited. Some headed for towns and cities but if they had no relatives in urban areas it was difficult to make a living. Others simply fled from South Sulawesi to other parts of Indonesia. It is difficult to estimate the number of South Sulawesi refugees during this period but statistics from Central Sumatra and Kalimantan cited by Lineton (1975: 23-24) give some indication: in 1956 local government officials in Central Sumatra estimated that there were 10,000 South Sulawesi refugees in Jambi and Riau and it is recorded that in the same year a further 5,000 arrived in East Kalimantan.

\section{QAHHAR MUDZAKKAR, KPPSI AND DARUL ISLAM}

Immediately after Qahhar was killed and the Darul Islam's armed resistance in South Sulawesi crushed, the New Order rose to power in Indonesia. During 
its period of rule (1965-1998), various Islamic groups were suppressed and the Ministry of Religion increased efforts to bureaucratise and standardise Islam through its control of religious education, Muslim marriages and Islamic courts. Traditionalists, members of South Sulawesi's Sufi brotherhoods and modernists were, in one way or another, co-opted by the regime. The Darul Islam movement was not, however, totally defeated. Some core members went underground and its remnants occasionally provided violent opposition to the New Order regime. Jemaah Islamiyah, the terrorist group responsible for the Bali bombings, is an offshoot of the wider Darul Islam and its members maintained contact with a hardcore of Darul Islam fighters from the 1950s and 1960s (International Crisis Group 2005: 5).

For most of the New Order period South Sulawesi remained mostly trouble free. There was little open discussion regarding the Darul Islam rebellion or Qahhar, who was officially cast as a traitor and an opponent of Indonesia and its Pancasila philosophy. Yet Qahhar continued to have appeal to many sections of society. He remained a common topic of private conversation with some believing he was still alive and one day would return to South Sulawesi. In fact, following the fall of the New Order, for a time some did think that Qahhar had returned when Kiyai Haji Syamsuri arrived in South Sulawesi in 1998 and began to attempt to speak and act like Qahhar. ${ }^{31}$ Syamsuri became very popular, despite being denied by some of Qahhar's family, and his sermons attracted large numbers of people, the recordings of which were sold in large numbers.

Syamsuri did not look like Qahhar and did not even have a South Sulawesi accent but such details were ignored by many and did little to dent his popularity. Eventually, in August 2000, Syamsuri withdrew from the limelight after a concerted appeal from Qahhar's family for him to stop..$^{32}$ That Syamsuri had little resemblance to Qahhar and was clearly an imposter did not deter people from wanting to believe that it was Qahhar and the whole episode was a clear demonstration of the continuing attraction and pull of Qahhar Mudzakkar at the end of the 20th and beginning of the 21st century.

Shortly after Syamsuri had retreated from his public impersonation, the on-going appeal of Qahhar, and to some extent Darul Islam, was again evident when KPPSI (Preparatory Committee for the Application of Islamic Laws) was founded in South Sulawesi in 2000, shortly after the enactment of the regional autonomy laws. Indeed, the secretary general of KPPSI openly stated that it was a continuation of Darul Islam but through constitutional means (ICG 2002a: 17). Qahhar has been relevant to KPPSI from its inception. He is not simply linked to KPPSI through a perceived shared "religious struggle" 
but also by way of genealogy as KPPSI is led by one of Qahhar's son's, Abdul Aziz Kahar Muzakkar (Aziz), who ran the Makassar branch of the Hidayatullah Pesantren. ${ }^{33}$ Shortly after KPPSI was established, Aziz stated that the Special Autonomy given to Aceh, which included the implantation of shari'ah, allows other provinces to demand the same special status. ${ }^{34}$

Not all KPPSI members are linked to Darul Islam as the organisation does contain a number of diverse Islamic groups, including moderates, whose members have been influenced by more recent history and international events. While KPPSI itself acts within the law and uses constitutional means, the link to Darul Islam's violent past has, however, been evident. Agus Dwikarna, a prominent member of KPPSI and one of its founding members, was mentored by Ale A. T., Qahhar Mudzakkar's former lieutenant (ICG 2005: 5). In July 2002, Agus was found guilty of carrying explosives in the Philippines and sentenced to a minimum ten years in prison (Tribunnews 2014). ${ }^{35} \mathrm{He}$ was also head of KPPSI's paramilitary wing, Laskar Jundullah (God's Soldiers), some of whom had fought in the Poso and Maluku conflicts (ICG 2002b: 35). In 2004, Laskar Jundullah members were also were also convicted of the bombing of a MacDonald's restaurant and a showroom in Makassar belonging to former vice-president and local businessman Jusuf Kalla. ${ }^{36}$ Since then, KPPSI has distanced itself from Laskar Jundullah, who are no longer officially part of the organisation.

In addition to campaigning for the implementation of shari'ah law at the provincial level, KPPSI has given direct support to the creation of shari'ah regulations in several kabupaten, such as Bulukumba, where the former bupati (regent), Patabai Pakokori, was a KPPSI member (Hamdan Juhannis 2007: 72). ${ }^{37}$ Many of these shari'ah regulations are seemingly symbolic in nature (Buehler 2007: 257) and as Jamhari Makruf and Iim Halimatussa'diyah (2014) have shown, were not so much driven by local demand or the influence of "Islamist" groups, but by political elites in an attempt to further their own political ambitions. ${ }^{38}$ In South Sulawesi and other regions of Indonesia, political elite interest in implementing shari'ah regulations declined when the desired political support they hoped it would bring failed to materialize (Jamhari Makruf and Iim Halimatussa'diyah 2014). Subsequent bupati of Bulukumba have shown considerably less interest in any enforcement of existing shari'ah regulations.

Qahhar is important to KPPSI and Aziz has invoked his ancestry as a means of strengthening support for himself and KPPSI. This has included the portrayal and promotion of South Sulawesi as a region with a strong deeprooted historical commitment to shari'ah law with Qahhar's struggle, and the 
support he received from the people, being a collective struggle for Islam. Qahhar is also portrayed as a national Islamic hero who was betrayed by the government, with his pre-1953 writings being largely ignored. With Aziz at the forefront of KPPSI, he is frequently in local news and a constant visible reminder of Qahhar, the romanticised symbol of the continuing struggle for shari'ah law in South Sulawesi.

In 2007, Aziz stood as a candidate in the South Sulawesi governorship election, which can perhaps be seen as a test of how strong support was for Qahhar, Darul Islam, KPPSI as well as Aziz himself, seven years after KPPSI's inception. None of the major parties supported Aziz's candidature at this time and Aziz came in third, gaining a significant 21 percent of the vote. During the election campaign, it was said that Aziz had planned to recruit prominent religious teachers to campaign on his behalf, which provoked a response from Qasim Mathar, a highly respected Islamic intellectual and professor at Universitas Islam Negeri Alauddin Makassar, who had previously spoken out against KPPSI. Qasim alluded to Qahhar's and Darul Islam's Islamic credentials by reminding Muslims not to use religion for political means as had Qahhar and the Darul Islam rebellion, thus causing great upheaval in South Sulawesi (Mujiburrahman 2013: 177). ${ }^{39}$

As the 2007 governorship election showed, Aziz (and perhaps Qahhar) did not have sufficient support from either political parties or the people of South Sulawesi but was popular enough to gain a fifth of the votes cast. In 2012, Aziz lowered his sights and stood as a deputy candidate to Ilham Arief Sirajuddin, the incumbent Mayor of Makassar. During the election Syahrul Yasin Limpo, the incumbent governor standing for re-election, alluded to Qahhar and the Darul Islam, calling on people to oppose the "rebels." Aziz was again on the losing side, with him and Ilham gaining 41 percent of the vote and Syahrul and his running mate just over 52 percent. Aziz again lost in 2018 when he stood as a deputy candidate to Nurdin Halid from the Golkar pary, who received only 27 percent of the vote (Tribun-Timur 2018).

In the 2014 Indonesian Presidential Election, Aziz and his family publicly supported Prabowo Subianto (TribunMakassar 2014), whose alliance included four of the five Islamic parties that had contested the legislative elections earlier that year and was backed by hard line Islamist groups, such as the Front Pembela Islam (Islamic Defenders' Front) and the Forum Ukhuwah Islamiyah (Islamic Brotherhood Forum). Support from the Qahhar Mudzakkar family, however, had little effect as over 71 percent of voters in South Sulawesi chose Joko Widodo and his running mate, Jusuf Kalla. An important factor in South Sulawesi's overwhelming support for the eventual 
winners was Jusuf Kalla, who is ethnically Bugis, suggesting that ethnic and regional affiliation continues to have the strongest pull on the people of South Sulawesi. To some extent his was also evident in the recent 2019 elections. Kalla was no longer the vice presidential candidate and influential factions within the Kalla family openly campaigned for Prabowo Subianto, both of which were important factors in Widodo's vote percentage dropping to 43 percent in the province..$^{40}$ Aziz again gave public support to Prabowo, again backed by hardline Islamist groups, but it is difficult at present to gauge how influential this support was in the province.

The name of Qahhar Mudzakkar continues to court controversy as supporters of KPPSI and similar organisations push his name forward in an attempt to have him proclaimed a national hero and dispel his portrayal as a rebel. For example, the Rektor of Universitas Islam Indonesia Yogyakarta, which already has a building named after Qahhar, has publicly stated that Qahhar should be proclaimed a national Indonesian hero for the service he gave to the country (Republika 2011; 2012). In 2012, Hamid Basma, the head of Dewan Koperasi Indonesia (Indonesian Cooperative Council) of South Sulawesi, challenged former South Sulawesi governor Andi Oddang to a local television debate after he had stated that "Qahhar Mudzakkar bukan pemberontak" (Qahhar Mudzakkar was not a rebel). Hamid admitted the statement angered him as Qahhar and his men murdered his family in Bulukumba (TribunMakassar 2012). Another of Qahhar's son's in Luwu announced plans to build a Universitas Kahar Muzakkar (Qahhar Mudzakkar University) (Republika 2011). More recently, Qahhar's name was even linked to ISIS (the Islamic State of Iraq and Syriah) when rumours spread, followed by newspaper reports, claiming his supporters were in the South Sulawesi port city of Parepare recruiting for ISIS. These rumours appear unfounded, but do appear to have been a deliberate attempt to link his name to the organisation as a means to gain sympathy, and perhaps recruits, for ISIS (Tribun-Timor 2015; TribunMakassar 2016).

While prominent Islamic intellectuals such as Qasim Mathar have spoken out against KPPSI, older and potentially more powerful opposition is also gathering momentum. Like KPPSI, its emergence and actions were made possible by the regional autonomy laws. In a recent article, Kathryn Robinson (2011) describes the rejuvenation of South Sulawesi cultural identities and traditions, including non-Islamic, which appears to be part of a wider cultural revival taking place in many other parts of Indonesia. ${ }^{41}$ In some areas, there has been a ceremonial re-instillation of the descendants of former rulers and regalia-centred ceremonies. The bissu too have been openly encouraged in 
some areas and are finding new avenues in cultural performances and in the promotion of South Sulawesi culture outside the region (Davies 2010: 204205). While this rejuvenation of local culture is partly an on-going reaction of people to its suppression by the New Order, it also functions as a platform for some of the hereditary elite as a route to political power. Nevertheless, these movements are a challenge to organisations such as KPPSI in their attempts to introduce shari'ah law.

The title of Robinson's article is "Sawerigading vs. Sharia." Sawerigading is the great Bugis cultural hero of the La Galigo epic literature who as a symbol of South Sulawesi traditions and culture appears to stand in opposition to Qahhar. Paradoxically, however, both Sawerigading and Qahhar share the very same South Sulawesi cultural qualities that bring admiration and attract followers: bravery, prowess, intelligence, supernatural ability, virility and defence of siriq. But Sawerigading is the archetypal to warani whose defence of siriq is unparalleled. For the time being at least, he remains a more popular and more powerful figure than Qahhar.

\section{CONCLUSION}

The debate as to whether Qahhar is a hero or villain in Indonesian and South Sulawesi history will doubtless continue for many years. Currently, this debate is played out in numerous internet blogs and forums with supporters, as with KPPSI, ignoring Qahhar's early less Islamic writings and the devastation and suffering his rebellion brought to the province, simply portraying him as an Islamic hero who fought for Indonesian independence but was betrayed by the central government who denied Islam a meaningful role in the constitution. Despite Qahhar's reinvention by those who have turned him into a romanticised figure in the struggle for shari'ah law in South Sulawesi, for many his attraction remains his opposition to the central government, regionalist ideas, and the possession of important traditional South Sulawesi cultural concepts. KPPSI's proposed special autonomy for South Sulawesi and the legalisation of shari'ah law has constantly struggled to gain sufficient support from the people and leading politicians of the province for it to become a viable proposition. Fifteen years after its inception, support for KPPSI continues to decline and the few shari'ah by-laws introduced in several regencies remain largely dormant and unpopular with some tainted by corruption. It appears that for the majority of South Sulawesi's inhabitants, the attraction of shari'ah 
law, albeit through constitutional means, remains no more attractive than it was in the 1950s and 1960s, when Qahhar and his followers attempted to force it on society as part of their rebellion.

\section{NOTES}

* Stephen Druce obtained his PhD in Southeast Asian history from the Centre for SouthEast Asian Studies at Hull University. He has published international articles and book chapters on the history, archaeology and literature of South Sulawesi and early Borneo. $\mathrm{He}$ is the author of The Lands West of the Lakes: A History of the Ajattappareng Kingdoms of South Sulawesi, 1200 to 1600 CE (KITLV Press, 2009) and Sebuah Sejarah Sulawesi Selatan dan Tradisi Lisan dan Tulisan, Abad ke-13 hingga ke-17 (Penerbit Ombak and KITLV Jakarta, 2016). He currently teaches Southeast Asian and Brunei history at Universiti Brunei Darussalam, where he is Programme Leader in Graduate Studies and Research in the Academy of Brunei Studies.

1 This is an updated version of a paper presented and distributed in 2013 at the 3rd Nicholas Tarling Conference on Southeast Asian Studies, Exalted Heroes, Demonized Villains and Losers: Altering Perceptions and Memories of Leaders and Leadership in Southeast Asia, c. 1800 - c. 2000, 12-13 November 2013, University of Malaya, Kuala Lumpur.

2 Qahhar is often assumed to be of the Bugis ethnic group. However, there are very few Bugis in Luwu and most people state they not Bugis but to Luwu (Luwu people) (Caldwell and Druce 1998). The language spoken by the vast majority of people in Luwu is bahasa Tai, which is a Toraja language.

3 Qahhar claimed to have been kidnapped by the guerrillas and taken into the jungle but it seems this was Qahhar's idea (van Dijk 1981:169-170).

$4 \quad$ Siriq and pessé are two cultural concepts found among all ethnic groups in South Sulawesi. I discuss them in a later section.

5 Summaries of Qahhar's life are generally consistent. I draw predominantly on Harvey (1974) and Hamdan Juhannis (2006).

6 His full name was Abdul Aziz Qahhar Mudzakkar but he is known simply as Qahhar Mudzakkar. The modern day spelling is Kahar Muzakkar. Both spellings are found in literature.

7 In this work Makasar (with one "s") refers to the ethnic group of that name and their language; Makassar refers to the historical kingdom and the capital of South Sulawesi, formerly Ujung Pandang.

8 In the Bugis language the word "domeng" means dominoes, while "La" is a male pronounal gender indicator. The name was given to Qahhar by his father because he was playing dominoes at the time of his birth (Hamdan Juhannis 2006: 32).

9 Hamdan Juhannis' assessment is based largely on Indonesian Army psychological reports. 
10 Harvey (1974: 198) further reports that there was some opposition to Qahhar's return in South Sulawesi. This was mainly from officials who had been involved in the shortlived State of East Indonesia (Negara Indonesia Timur) and pro-republican aristocrats who thought Qahhar may begin a "social revolution," targeting those who cooperated with the Dutch and attempt to eliminate the aristocracy.

11 David Bulbeck's (1996: 301) detailed analysis of Makasar ranks, which are similar to the Bugis, demonstrates that within the ruling elite a man's status was continually "reassessed in accordance with personal achievement."

12 See Druce (2016 and 2017: 23-25) for further discussions on this.

13 The latoa is largely a collection of instructions, much of which are clearly derived from oral tradition, mainly concerned with the correct behaviour of rulers towards the people and the people among themselves. See Mattulada (1985) for an Indonesian translation of some latoa material.

14 The son of the Luwu's last ruler, Andi Makkulau, informed Harvey of Qahhar's descent. In a conversation I had with Andi Anton (a high-ranking and respected Luwu noble) some years ago, he informed me that Qahhar's family lay in the grey area between noble and commoners.

15 Many Bugis have long disputed the negative assessment of Arung Palakka in the official version of Indonesian history, informing me that Arung Palakka should be proclaimed a national hero as he was the first person in South Sulawesi to fight against colonialism, which was the colonialism of the Makassar kingdoms of Gowa and Talloq.

16 Dutch reports tell us that Arung Palakka was actually of small stature. The story of his extremely large genitalia probably functions to conceal the fact that Arung Palakka was impotent, as despite all his wives, he had no children.

17 This particular story probably has its origins in Qahhar's own writings that have been elaborated after entering the oral register. He wrote "Sedjak masa ketjil saja tidak pernah ditundukkan oleh lawan-lawan saja dalam perkelahian dan sedjak dewasa saja tidak pernah mendjadi 'Pak Toeroet' pendapat seseorang di luar adjaran Islam” (Ever since I was a child I have never been beaten by opponents in a fight and since becoming an adult I have never become a "yes-man" to anyone outside the teachings of Islam) (Abdul Kahar Muzakkar 2005). As far as I can ascertain, the first printing of the short work containing this sentence was in 1960.

18 Several informants stated that some of Qahhar's wives were those of fallen comrades and he had married them out of Islamic or social responsibility.

19 Lineton's anthropological study presents a detailed analysis of Bugis village society in the context of understanding the factors conducive to outward migration.

20 Hamdan Juhannis (2006: 10) defines the term "formalist Islam" as the "belief that Islam must not be separated from state affairs."

21 For example, Qahhar's first written ideological formulation of the state's basis in 1950, called "Revolusi Kemerdekaan Sedjati." This is secular in tone and uses what may be interpreted as left-wing terminology, or at least phraseology.

22 See also Esther Velthoen (2004).

23 These arguments are set out in Qahhar's booklet, Konsepsi negara demokrasi Indonesia: Koreksi pemikiran politik pemerintahan Soekarno (A plan for a democratic state of Indonesia: A correction to the political thinking of the Sukarno government). An English language extract of this booklet is found in Feith and Castles (1970: 330-335). 
24 Like Qahhar, Usman Balo is considered a to warani. Many stories are told by people in kabupaten (regency) Sidrap about his bravery, supernatural powers and his huge number of wives. Pelras (2000: 409) reports that Usman Balo's wives formed a large group of armed women who always accompanied him.

25 As Hamdan Juhannis (2006: 57) points out, the departure of these figures and their battalions who did not agree with Darul Islam helped to purify the Islamic orientation of the Qahhar's rebellion.

26 I first went to South Sulawesi in 1996-1997 as a student at Hasanuddin University for one year, where I carried out research for an undergraduate project. I returned to work on several historical and archaeological projects in 1998 and 1999 and then in 2000-2001 for my PhD research. Subsequently I have spent considerable time in South Sulawesi, some of it carrying out further research. The information presented below from interviews and conversations with people was thus drawn over a long period. I have decided not to name any of the informants as some would prefer to remain anonymous on this subject while others have since died.

27 Westerling led a Dutch counter-insurgency operation in South Sulawesi. Indonesian authorities claim he was responsible for some 40,000 deaths. While the real figure is undoubtedly much lower, this does not detract for viciousness and terror of Westerling's operation.

28 In this context it is perhaps not surprising to note that South Sulawesi was a Golkar stronghold throughout much of the New Order period and Golkar remains the most popular of the political parties in South Sulawesi.

29 Often mentioned here is the decision to remove seven words that are believed to have been briefly incorporated into the 1945 constitution shortly before its promulgation, which stipulated that all Muslims should observe Islamic law. Their removal thus reduced any formal role that Islam would have played in the political and social life of the new republic.

30 I should point out that accounts told to both Harvey (1974) and Lineton (1975) by people about the rebellion were generally more negative than those told to me thirty or so years later.

31 I was in South Sulawesi at the time of the Syamsuri-Qahhar phenomenon.

32 Syamsuri is said to have died in 2006.

33 The Hidayatullah Pesantren network was established by an adjutant of Qahhar in East Kalimantan in the early 1970s and through its journal, Suara Hidayatullah, openly backed radical Islamic movements (Bruinessen 2013: 11).

34 From his article in the South Sulawesi newspaper, Fajar, 2 June 2000.

35 Dwikarna was released on the 31 December 2013; he returned to Makassar the following day.

36 According to the International Crisis Group (2003: 15), while Laskar Jundullah was officially the security arm of KPPSI, in reality it had been "established with the help of al-Qaeda."

37 Patabai Pakokori was bupati from 1995-2000 and 2000-2005. He brought in four shari'ah regulations: bans on alcohol and gambling, enforced wearing of the headscarf, and zakat (Islamic alms giving) (Hamdan Juhannis 2007: 72). 
38 Buehler (2007) has shown how political elites in Bulukumba used zakat collection to generate revenue that was used to maintain their own political and patronage networks. Buehler further states that when Patabai Pakokori was bupati some of the zakat revenue was given to petty criminals and thugs to be part of Laskar Jundullah who would then help implement the shari'ah regulations on the streets.

39 A report made available by Wikileaks states that a prominent academic from the university criticised those who used implementation of shari'ah law as a political tool in the gubernatorial elections. The report further stated that Amin Syam, the governor at the time who was standing for re-election, gave the appearance of supporting the implementation of shari'ah law but only to attract votes and would not follow this through (WikiLeaks n.d.). Amin Syam lost the election.

40 While Yusuf Kalla remained supportive of Jokowi in the election, the fact that he would no longer play an influential role in government was prominent in people's thoughts.

41 See, for example, Davidson and Henley (2007).

\section{REFERENCES}

Abdul Aziz Qahar Muzakkar. 2000. Otonomi khusus Aceh dan Sulsel. Fajar, 2 June.

Abdul Kahar Muzakkar. 1960/2005. Revolusi ketatanegaraan Indonesia: Menudju persaudaraan manusia. Makassar: toACCAe Publishing.

Andaya, L. Y. 1981. The heritage of Arung Palakka: A history of South Sulawesi (Celebes) in the seventeenth century. The Hague: Nijhoff.

Anhar Gonggong. 1992. Abdul Qahhar Mudzakkar dari patriot hingga pemberontak. Jakarta: Grasindo.

Bahar Mattalioe. 1965. Kahar Muzakkar dan petualangannja. Djakarta: Penerbit Delegasi.

Bruinessen, M. van. 2013. Introduction: Contemporary developments in Indonesian Islam and the "conservative turn" of the early twenty-first century. In Contemporary developments in Indonesian Islam: Explaining the "conservative turn,” ed. van Bruinessen, M., 1-20. Singapore: ISEAS Publishing. https://doi. org/10.1355/9789814414579-005

1991. The tariqa Khalwatiyya in South Celebes. In Excursies in Celebes: Een bundle bijdragen bij het afscheid van J. Noorduyn, eds. Poeze, H. A. and Schoorl, P., 251-269. Leiden: KITLVE Press.

Buehler, M. 2007. The rise of Shari'a by-laws in Indonesian districts: An indication for changing patterns of power accumulation and political corruption. South East Asia Research 16 (2): 255-285. https://doi.org/10.5367/000000008785260473

Bulbeck, F. D. 1996. The politics of marriage and the marriage of polities in Gowa, South Sulawesi, during the 16th and 17th centuries. In Origins, ancestry, and alliance: Explorations in Austronesian ethnography, eds. Fox, J. J. and Sather, C., 280-315. Canberra: Department of Anthropology, Research School of Pacific and Asian Studies, Australian National University. https://doi.org/10.22459/OAA.10.2006.13

Caldwell, I. and Druce, S. 1998. The tributary and domain lists of Luwu, Binamu and Bangkala. Unpublished report to the South-East Asia Committee of the British Academy. https://oxis.org/resources-3/papers-unpublished/caldwell--druce-1998 .pdf (accessed 15 Jan 2019). 
Davidson, J. S. and Henley, D. (eds). 2007. The revival of tradition in Indonesian politics: The deployment of adat from colonialism to indigenism. London: Routledge. https://doi.org/10.4324/9780203965498

Davies, S. G. 2010. Gender diversity in Indonesia: Sexuality, Islam and queer selves. London: Routledge. https://doi.org/10.4324/9780203860953

Druce, S. C. 2009. The lands west of the lakes: A history of the Ajattappareng kingdoms of South Sulawesi 1200 to 1600 CE. Leiden: KITLV Press. https://doi.org/10.26530/ OAPEN_381395

2016. Transmitting the past in South Sulawesi: The Hikajat Sawitto and other Bugis and Makasar historical works. In Orality, writing and history: The literature of the Bugis and Makasar of South Sulawesi, ed. Druce, S. C. International Journal of Asia Pacific Studies 12 (Supp. 1): 73-117. https://doi.org/10.21315/ijaps2016 $.12 . \mathrm{s} 1.5$

2017. The decentralized Austronesian polity: Of Mandalas, Negaras, Galactics, and the South Sulawesi Kingdoms. Suvannabhumi: Multi-disciplinary Journal of Southeast Asian Studies 9 (2): 7-34.

Feith, H. and Castles, L. (eds). 1970. Indonesian political thinking, 1945-1965. Ithaca: Cornell University Press.

Hamdan Juhannis. 2006. The struggle for formalist Islam in South Sulawesi: From Darul Islam (DI) to komite persiapan penegakan syariat Islam (KPPSI). PhD diss., Australian National University.

2007. Komite Persiapan Penegakan Syariat Islam: A South Sulawesi formalist Islamic movement. Studi Islamika: Indonesian Journal for Islamic Studies 14 (1): 47-84. https://doi.org/10.15408/sdi.v14i1.557

Hamid Abdullah. 1985. Manusia Bugis-Makassar: Satu tinjauan histories terhadap tingkah laku dan pandangan hidup manusia Bugis Makassar. Jakarta: Inti Idayu.

Harvey, B. S. 1974. Tradition, Islam and rebellion: South Sulawesi 1950-1965. $\mathrm{PhD}$ diss., Cornell University.

Ichlasul Amal. 1992. Regional and central government in Indonesian politics: West Sumatera and South Sulawesi 1949-1979. Yogyakarta: Gadjah Mada University Press.

International Crisis Group. 2002a. Al-Qaeda in Southeast Asia: The case of the "Ngruki Network" in Indonesia. Asia Briefing, no. 20.

2002b. Indonesia backgrounder: How the Jemaah Islamiyah terrorist network operates. Asia Report, no. 43.

2003. Jemaah Islamiyah in South East Asia: Damaged but still dangerous. Asia Report, no. 63.

2005. Recycling militants in Indonesia: Darul Islam and the Australian Embassy Bombing. Asia Report, no. 92.

Jamhari Makruf and Iim Halimatussa'diyah. 2014. Shari'a and regional governance in Indonesia: A study of four provinces. Australian Journal of Asian Law 15 (1): 1-15.

Lineton, J. 1975. An Indonesian society and its universe: A study of the Bugis of South Sulawesi (Celebes) and their role within a wider social and economic system. $\mathrm{PhD}$ diss., School of Oriental and African Studies, University of London. 
Matthes, B. F. 1874. Boegineesch-Hollandsch woordenboek, met Hollandsch-Boeginesche woordenlijst, en verklaring van een tot opheldering bijgevoegden ethnographischen atlas. Amsterdam: Nijhoff.

Mattulada. 1983. Kahar Muzakkar: Profil patriot pemberontak. In Manusia dalam kemelut sejarah, eds. Taufik Abdullah, Aswab Mahasin and Dhakidae, D., 174-188. Jakarta: Lembaga Penelitian, Pendidikan dan Penerangan Ekonomi dan Sosial.

1985. Latoa: Satu lukisan analitis terhadap antropologi politik orang Bugis. Yogyakarta: Gadjah Mada University Press.

Millar, S. B. 1989. Bugis weddings: Rituals of social location in modern Indonesia. Berkeley: Center for South and Southeast Asian Studies, University of California.

Mujiburrahman. 2013. The politics of Shariah: The struggle of KPPSI in South Sulawesi. In Contemporary developments in Indonesian Islam: Explaining the "conservative turn," ed. van Bruinessen, M., 145-189. Singapore: ISEAS Publishing. http://dx.doi.org/10.1355/9789814414579-009

Pelras, Ch. 1996. The Bugis. Oxford: Blackwell. 2000. Patron-client ties among the Bugis and Makassarese of South Sulawesi. Bijdragen tot de Taal-, Land-en Volkenkunde 156 (3): 393-432.

Republika. 2011. Keluarga Kahar Muzakkar akan bikin universitas. https://www .republika.co.id/berita/nasional/umum/11/11/01/ltz5lv-keluarga-kahar-muzakkarakan-bikin-universita (accessed 10 October 2013).

. 2012. UII: Kahar Muzakkar layak jadi pahlawan nasional, https://www.republika. co.id/berita/nasional/umum/12/04/13/m2eza7-uii-kahar-muzakkar-layak-jadipahlawan-nasional (accessed 10 October 2013).

Robinson, K. 2011. Sawerigading vs. Sharia: Identities and political contestation in decentralised Indonesia. Asian Journal of Social Sciences 39 (2): 219-237. https://doi.org/10.1163/156853111X565896

Thompson, Tommy. 2002. Menyingkap misteri Abdul Qahhar Mudzakkar. Surabaya: Lutfansah Mediatama.

TribunMakassar. 2012. Basma tantang Oddang bahas Qahhar Mudzakkar di televisi. https://makassar.tribunnews.com/2012/08/08/basma-tantang-oddang-bahasqahhar-mudzakkar-di-televisi (accessed 05 October 2013).

. 2014. Keluarga Qahhar Mudzakkar ke Prabowo. https://makassar.tribunnews. com/2014/06/17/keluarga-kahar-muzakkar-ke-prabowo (accessed 05 December 2018).

2016. Danrem 142 taro ada taro gau: Tak ada pengikut Kahar Muzakkar. https://makassar.tribunnews.com/2015/03/19/danrem-142-taro-ada-taro-gau-takada-pengikut-kahar-muzakkar (accessed 05 December 2018).

Tribunnews. 2014. Filipina bebaskan Agus Dwikarna setelah ditahan lebih 11 tahun. https://www.tribunnews.com/nasional/2014/01/03/filipina-bebaskan-agusdwikarna-setelah-ditahan-lebih-11-tahun (accessed 05 December 2018).

Tribun-Timor. 2015. Begini cara Polres Parepare antisipasi ISIS di daerahnya. https://makassar.tribunnews.com/2015/03/19/begini-cara-polres-parepareantisipasi-isis-di-daerahnya (accessed 05 December 2018).

Tribun-Timur. 2018. Berikut perolehan suara empat Cagub hasil rekap KPU Sulsel. https://makassar.tribunnews.com/2018/07/09/berikut-perolehan-suara-empatcagub-hasil-rekap-kpu-sulsel?page=4 (accessed 05 December 2018). 
van Dijk, C. 1981. Rebellion under the banner of Islam: The Darul Islam in Indonesia. The Hague: Martinus Nijhoff. https://doi.org/10.26530/OAPEN_613352

Velthoen, E. 2004. Hutan and kota: Contested visions of the nation-state in southern Sulawesi in the 1950s. In Indonesia in transition: Rethinking civil society, region, and crisis, eds. Samuel, H. and Nordholt, H. S., 147-174. Yogyakarta: Pustaka Pelajar.

Wanua Tangke, A. 2002. Misteri Kahar Muzakkar masih hidup. Makassar: Pustaka Refleksi. WikiLeaks. n.d. South Sulawesi: Playing politics with Shariah Law. http://wikileaks.org/ cable/2007/09/07SURABAYA39.html (accessed 10 September 2013). 